\title{
Orthotrichum affine var. bohemicum (Orthotrichaceae), a new variety of epiphytic moss from the Czech Republic
}

\author{
Vítězslav Plášek ${ }^{1 *}$, Jakub Sawicki ${ }^{2}$ I Ivana Marková ${ }^{3}$, Sylwia Wierzcholska ${ }^{4}$ \\ ${ }^{1}$ Department of Biology \& Ecology, University of 0strava, Chittussiho 10,710 00 0strava, (zech Republic \\ 2 Deparment of Botany and Nature Protection, University of Warmia and Mazury in Olsztyn, 10-728 Olsztyn, Poland \\ ${ }^{3}$ Bohemian Switzerland National Park Administration, Pražská 52, 40746 Krásná Lípa, Czech Republic \\ ${ }^{4}$ Department of Biodiversity and Plant Cover Protection, Wrockaw University, Kanonia 6/8, 50-328 Wrockaw, Poland
}

\section{Abstract}

Orthotrichum affine var. bohemicum Plášek \& Sawicki, var. nova, is a confirmed record of a new variety from the Czech Republic. The new taxon is described and illustrated by photos and drawing. It is characterized by having superficial stomata and a peristome with 16 endostome segments (practically as long as exostome teeth). Molecular data indicating the phylogenetic placement of the species are presented.

Keywords: Orthotrichum affine var. bohemicum, Orthotrichum affine, Orthotrichum pallens, mosses, new variety, taxonomy, Czech Republic

\section{Introduction}

The genus Orthotrichum is a widespread moss group, which includes approximately 155 species [1]. Taxa belonging to this genus are found throughout the world from the Arctic to the Antarctic, avoiding only deserts and wet tropical forests. Species of the genus Orthotrichum grow on trees and rocks to a height of ca. $5000 \mathrm{~m}$ a.s.l. [2].

In the Czech Republic there were until recently 20 known taxa [3]. Subsequently in 2009, new species of O. moravicum have been added [4].

\section{Material and methods}

During a bryofloristic survey in the Protected Landscape Area Lužické hory Mts. (NW part of the Czech Republic) in October 2006 a noteworthy epiphytic moss from the genus Orthotrichum was collected (Fig. 1). Upon closer examination the specimen proved to represent a variety new to science.

\section{Type localization}

Europe, Czech Republic, Prov. Bohemia, PLA Lužické hory

*Corresponding author. Email: vitezslav.plasek@osu.cz

This is an Open Access digital version of the article distributed under the terms of the Creative Commons Attribution 3.0 License (creativecommons.org/licenses/by/3.0/), which permits redistribution, commercial and non-commercial, provided that the article is properly cited.
Mts., $0.9 \mathrm{~km}$ NNW center of the village Doubice, a small group of Fraxinus excelsior in a man-made spruce forest by the trail called "Vápenná cesta" (green marked tourist trail), $100 \mathrm{~m}$ from the road from Kyjov towards the village Doubice, $414 \mathrm{~m}$ a.s.l., coordinates (WGS 84): $\mathrm{N}=50^{\circ} 53^{\prime} 44^{\prime \prime}$ and $\mathrm{E}=14^{\circ} 27^{\prime} 21^{\prime \prime}$, leg. I. Marková 2006.10.18 (herb. OP, KRAM \& priv. herb. I. Marková \#142/2006).

We are pleased to name the variety after the province Bohemia of the Czech Republic, where the type material has been found.

The nomenclature of the moss taxa in the text below follows Hill et al. [5], hepatics are dealt with Grolle and Long [6] and vascular plants follow Kubát et al. [7].

\section{Results and discussion}

\section{Orthotrichum affine var. bohemicum Plášek \& Sawicki, var. nova}

Plantae usque ad $1.6 \mathrm{~cm}$ altae, cum foliis erecto-adpressis, lanceolatis, apicis acutis. Cellulae superiores cum 1-2 papillis altis, bifurcatis sive conicis. Capsulae fere cunctae emergentes, cylindricae vel oblongo-cylindricae. Stomata phaneropora, in media parte capsulae locata. Peristomium duplex; exostomium 8 dentium (plerumque senectis in 16 fissis), in sicco recurvatum, in basi papilloso-striatum, in dimidio superiore papillosum; endostomium tam-quam exostoma longum, 16 segmentis glabris (planum externum) et papillosis (planum internum), uniseriatis et biseriatis segmentis alternis. Calyptra oblongo-conica, in dimidio superiore dense hirsuta.

\section{Description}

Plants pale green, 11-16 mm tall, in the central part of 


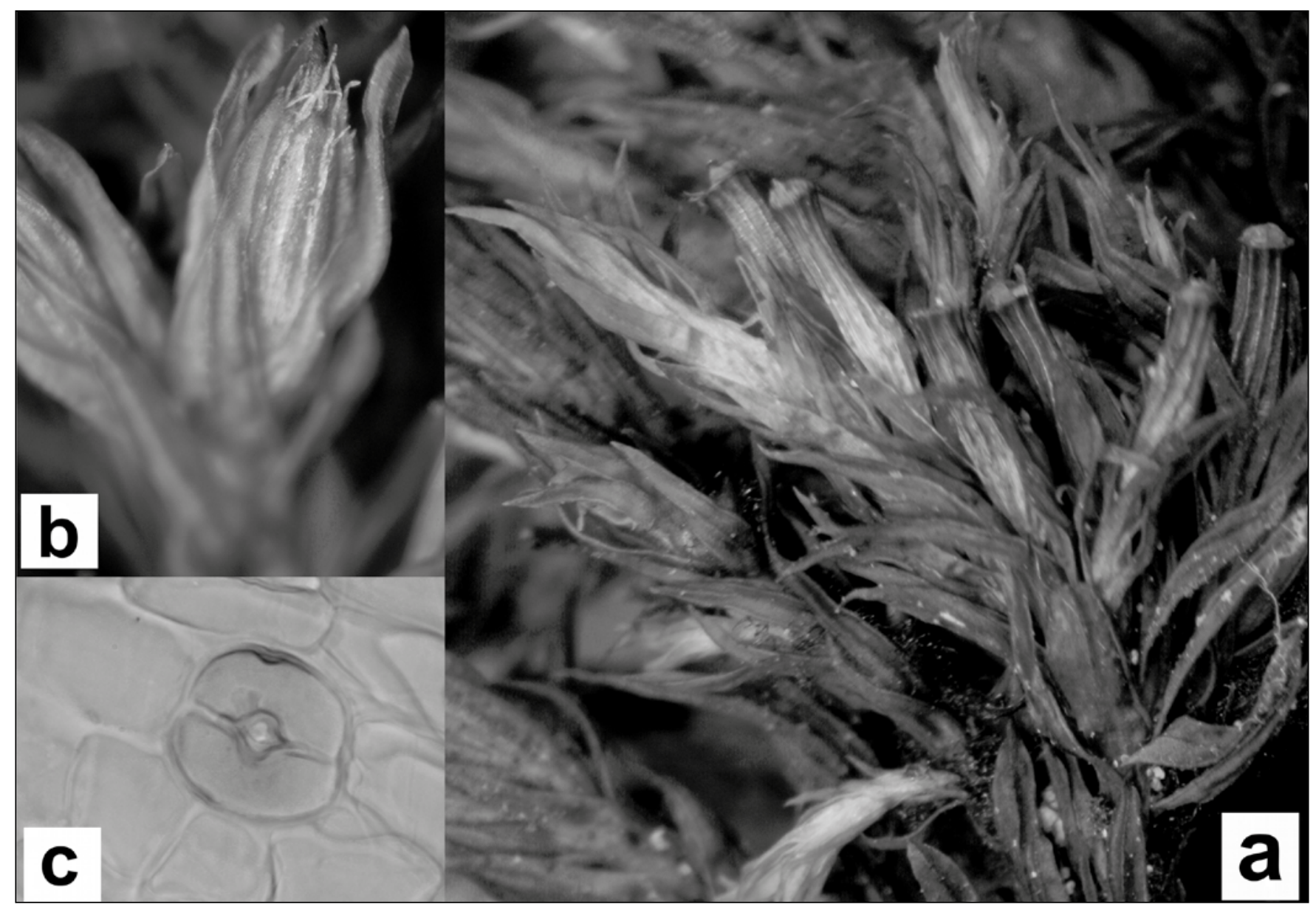

Fig. 1 Photomicrographs of Orthotrichum affine var. bohemicum. a Habit. b Hidden capsule with hairy calyptra. c Superficial stomata. Photos of the holotype specimen were made by V. Plášek.

sparse cushions up to $2.5 \mathrm{~cm}$. Stem densely branched (Fig. 1), branches up to $5 \mathrm{~mm}$ long. Rhizoids pale brown, branched, smooth densely distributed along the stem. Stem leaves erectappressed and slightly incurved when dry, erect when moist, elongate to lanceolate in shape, $1.3-1.8 \mathrm{~mm}$, keeled, acuminate, sharply acute; margins recurved (Fig. 2f, Fig. 3b) from base to near apex, entire. Upper laminal cells rounded in the apex (9-)10-12(-13) $\mu \mathrm{m}$, oval to elliptic in the middle of the leaves, (9-)10-12(-13) $\times$ 8-10 $\mu \mathrm{m}, 1$-stratose, with $1(-2)$ fairly tall forked or conical papillae (3-6 $\mu \mathrm{m})$; basal laminal cells longrectangular to elongate, slightly nodose, $8-10 \times 30-50 \mu \mathrm{m}$ wide. Costa ending near apex, in basal part (75-)80(-90) $\mu \mathrm{m}$ wide, near apex (28-)35(-40) $\mu \mathrm{m}$ wide. Sexual condition goniautoicous. Seta $0.8-1.2 \mathrm{~mm}$, ochrea up to $1 / 6$ of the seta, vaginula naked. Capsule emergent, from 2/3 to 3/4 exserted (Fig. 1); urn-shaped cylindrical when dry, oblong-cylindrical when moist, 2.2-2.6 mm long, yellowish brown or pale brown with 8 strong ribs that do not reach the capsule base, contracted to $3 / 4$ or along entire length when old. Exothecial bands 4 cells wide, formed by moderately differentiated exiguous thickwalled cells, extending from the mouth to $2 / 3$ or $3 / 4$ of capsule length. Neck concolorous with theca, gradually narrowed to the seta. Stomates superficial (Fig. 1c, Fig. 2e, Fig. 3i), situated in the central part of the capsule. Peristome double (Fig. 3a). Endostome formed by 16 segments, whitish to pale brown, incurved when dry, smooth on external side, coarsely papillose on internal side; principal segments biseriate (at least at base), (176-)180-185(-195) $\mu \mathrm{m}$ long, intermediate ones as tall as principal ones or a little shorter, (170-)175-180(-186) $\mu \mathrm{m}$ long, consisting of a single row of cells. Exostome teeth 8 (usually split into 16 when old), light brown, 191-200 $\mu \mathrm{m}$ long, strongly recurved when dry. Ornamentation (Fig. 3) of the external side (OPL): papillose - striate at base and coarsely papillose to reticulate-papillose in the upper part. The internal side (PPL) roughly ornamented with papillae. Exostome teeth often remarkably cleft or perforated in upper parts. Calyptra conic-oblong, light brown, in the upper part hairy with papillose hairs (Fig. 1b, Fig. 2c). Lid not seen. Spores 13-15 $\mu$, densely papillose (Fig. $3 \mathrm{~h}$ ). Asexual propagules not seen.

Orthotrichum affine var. bohemicum is similar to type $O$. affine in terms of many gametophytic and sporophytic characters, but it can be easily distinguished based on 16 endostome segments (practically as long as exostome teeth) and smaller spore size of 13-15 $\mu \mathrm{m}$ (normal O. affine has spore size of 14-26 $\mu \mathrm{m})$ in O. affine var. bohemicum. Orthotrichum pallens, which seems superficially related to the above species, can be differentiated from them primarily due to the cryptopore type of stomates and shorter and blunter ended leaves. In addition, $O$. pallens has endostome segments alternately longer and shorter, whereas in O. affine var. bohemicum all segments are equally long (practically as long as exostome teeth).

\section{Ecology and distribution of 0 . affine var. bohemicum}

The new variety was firstly observed growing on the bark of Fraxinus excelsior, in the lower vertical part of the trunk, on the southwestern side, at a height of $72 \mathrm{~cm}$; the population size was $7.5 \mathrm{~cm}^{2}$, and it was accompanied by Brachythecium salebrosum, B. velutinum and Chiloscyphus profundus. The 


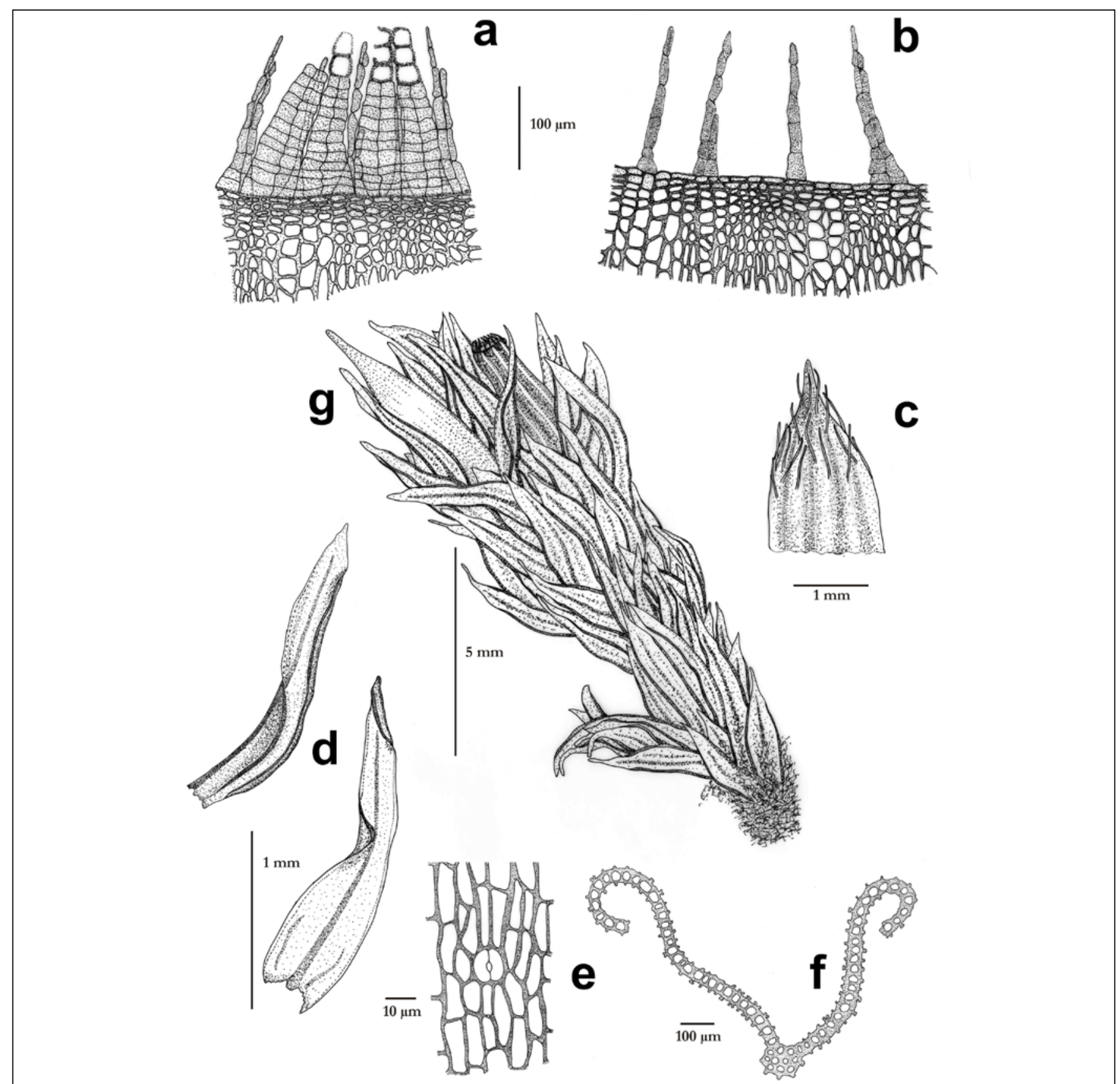

Fig. 2 Orthotrichum affine var. bohemicum. a Peristome. b Detail of endostome segments after exostome teeth were cut off. c Calyptra. $\mathbf{d}$ Leaves. e Superficial stomata. f Transverse section of leaf. $\mathbf{g}$ Habit. Scale bars are given for every picture. Drawings of holotype by Sylwia Wierzcholska.

tree was growing within a small group of Fraxinus excelsior in a man-made spruce forest, by the road (Fig. 4). After the specimen had been identified and confirmed as a new species, a detailed survey of the locality was carried out. In July 2009, two new populations of $O$. affine var. bohemicum were found on another Fraxinus excelsior tree in the proximity of the first one. Both populations were growing at heights of 100 and 120 $\mathrm{cm}$ above ground, together with Brachythecium salebrosum. The size of the lower-growing population was $4.5 \mathrm{~cm}^{2}$, and that of the upper-growing one was $3 \mathrm{~cm}^{2}$.

\section{Molecular analysis}

A list of species used in the molecular analysis, details concerning voucher data, and GenBank accession numbers are given in the Appendix S1. Total genomic DNA was extracted using DNeasy Plant Mini Kit (Qiagen). Single stems were ground with silica in a Mini-Beadbeater-1 tissue disruptor for
$40 \mathrm{~s}$ and subsequently treated with kit reagents following the manufacturer's protocol. Extracted DNA samples were stored at $-20^{\circ} \mathrm{C}$. For amplification and sequencing of ITS we used the primers of Fiedorow et al. [8], which were successfully used in previous studies on genus Orthotrichum [4,9-12]. The ITS were amplified in a volume of $25 \mu$ containing $20 \mathrm{mM}\left(\mathrm{NH}_{4}\right)$ $\mathrm{SO}_{4}, 50 \mathrm{mM}$ Tris- $\mathrm{HCl}\left(\mathrm{pH} 9.0\right.$ at $\left.25^{\circ} \mathrm{C}\right), 1.5 \mathrm{mM} \mathrm{MgCl}_{2}, 1 \mu \mathrm{l}$ BSA, $200 \mu \mathrm{M}$ each dATP, dGTP, dCTP, dTTP, $1.0 \mu \mathrm{M}$ of each primer, one unit of Taq polymerase (Novazym) and $1 \mu \mathrm{l}$ of the DNA solution. The reaction was processed at $94^{\circ} \mathrm{C}$ for $1 \mathrm{~min}$ followed by 30 cycles at $94^{\circ} \mathrm{C}$ for $1 \mathrm{~min}, 59^{\circ} \mathrm{C}$ for $1 \mathrm{~min}$, and $72^{\circ} \mathrm{C}$ for $1.5 \mathrm{~min}$, with a final extension step of $72^{\circ} \mathrm{C}$ for $5 \mathrm{~min}$. Finally $5 \mu \mathrm{l}$ of the amplification products were visualized on $1.5 \%$ agarose gel with ethidium bromide staining. Purified PCR products were sequenced in both directions using ABI BigDye 3.1 Terminator Cycle Kit (Applied Biosystems) and then visualized using an ABI Prism 3130 Automated DNA Sequencer 


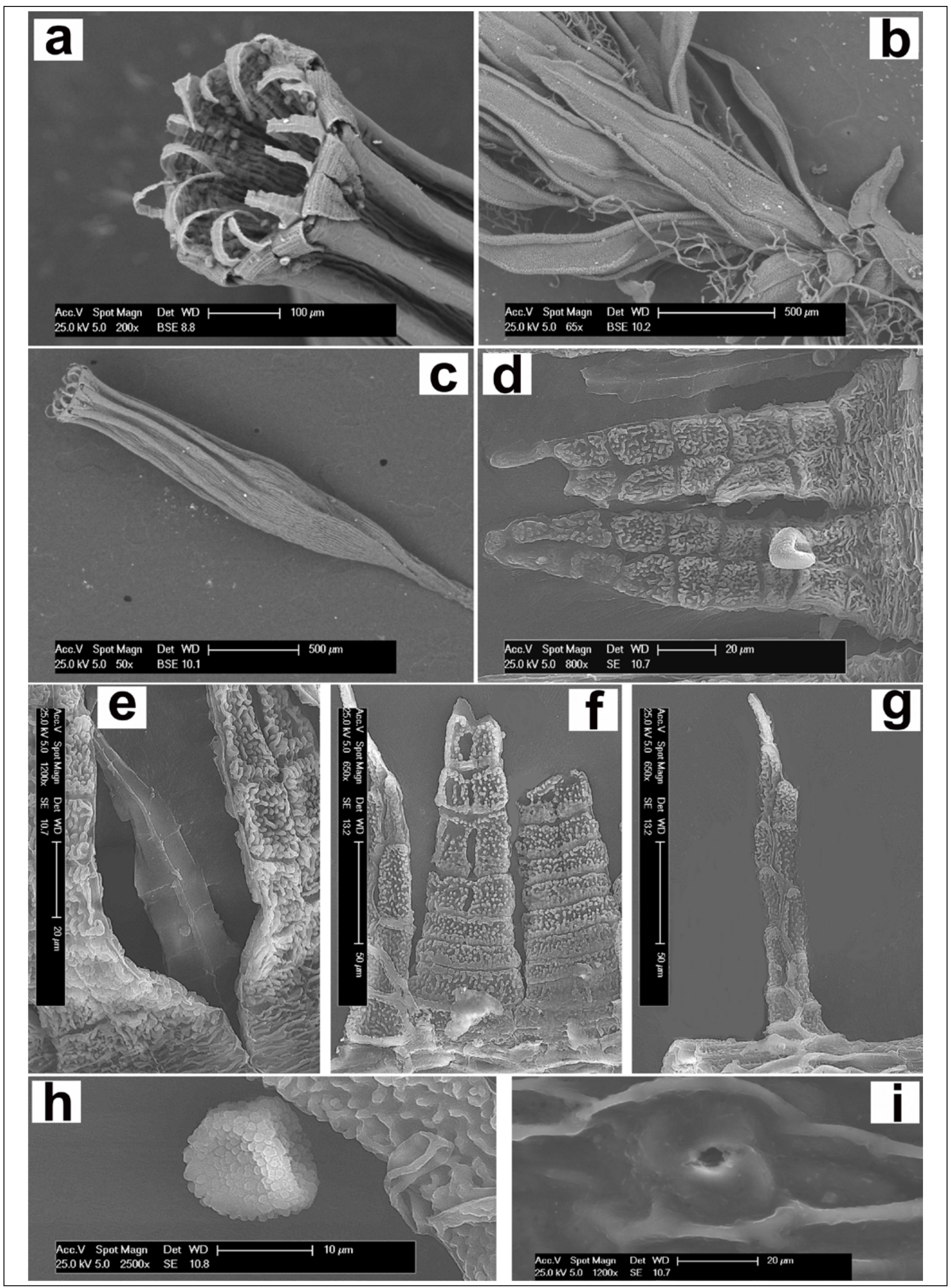

Fig. 3 SEM micrographs of Orthotrichum affine var. bohemicum. a Peristome. b Leaves (with recurved margins). c Capsule shape. d,e. External view of peristome showing OPL ornamentation of the exostome and PPL ornamentation of the endostome. $\mathbf{f}$ PPL ornamentation of the exostome. $\mathbf{g}$ Endostome segment showing IPL ornamentation. $\mathbf{h}$ Spore. $\mathbf{i}$ Detail of pore. Photos of the holotype specimen were made by V. Plášek and G. Kratošová. 


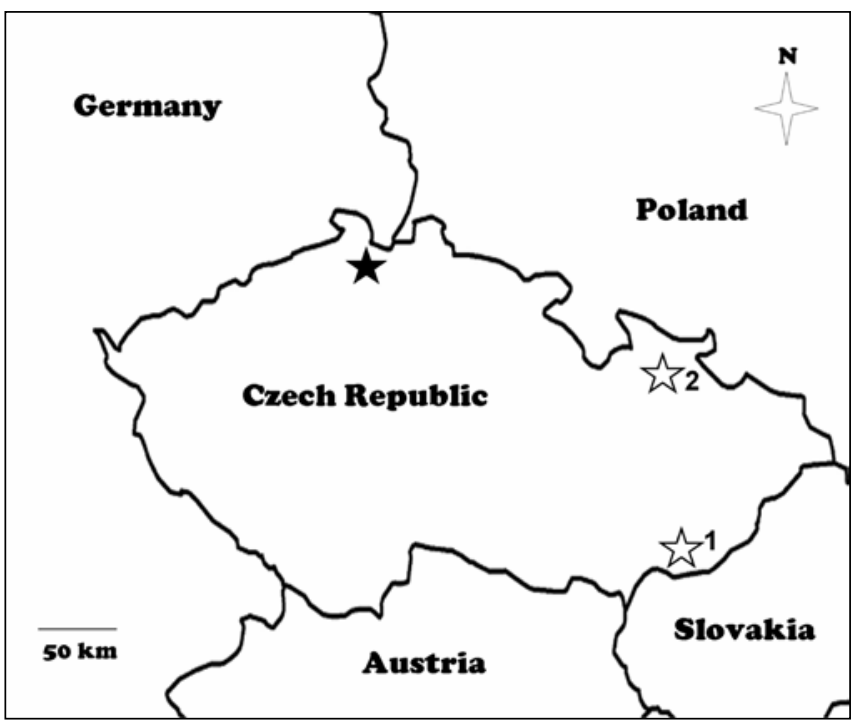

Fig. 4 Map of Central Europe marking the type locality of Orthotrichum affine var. bohemicum - black star [coordinates (WGS 84): N $=50^{\circ} 53^{\prime} 44^{\prime \prime}$ and $\left.\mathrm{E}=14^{\circ} 27^{\prime} 21^{\prime \prime}\right]$ and another two known localities white stars (for description see the text in "Conclusion").
(Applied Biosystems). The assembled sequences were aligned using Muscle 3.6 [13] and manually adjusted with BioEdit 7 [14]. Phylogenetic analyses were conducted using Minimum Evolution (ME) analysis [15] as implemented in MEGA 4 [16]. The pairwise distances were estimated with the Kimura 2-parameter method [17] and initial trees were generated using the neighbor-joining (NJ) method. The ME tree was searched using the Close Neighbor Interchange (CNI) algorithm [18] at a search level of 2 , and the maximum number of trees retained at each step was set to 100. Bootstrap analysis [19] was carried out with 1000 replicates.

A combined dataset included 984 characters, of which 849 were constant, 33 variable but parsimony-uninformative and 102 potentially phylogenetically informative. The tree based on ME analysis revealed three well-supported clades (Fig. 5). Clade A (BS 100\%) is formed by O. pulchellum and O. stramineum, i.e. species with immersed stomata, which were used as an outgroup based on previous studies $[9,11]$. The specimens of the dioecious O. lyellii formed clade B (BS 100\%), which suggests its distinctiveness from monoecious members of the subgenus Gymnoporus, which were included in clade C. Within this group, an analysis of ITS revealed the specimens of $O$. affine var. bohemicum to represent a sister group to $O$. affine, but clearly separate (BS 90\%) from the species, which

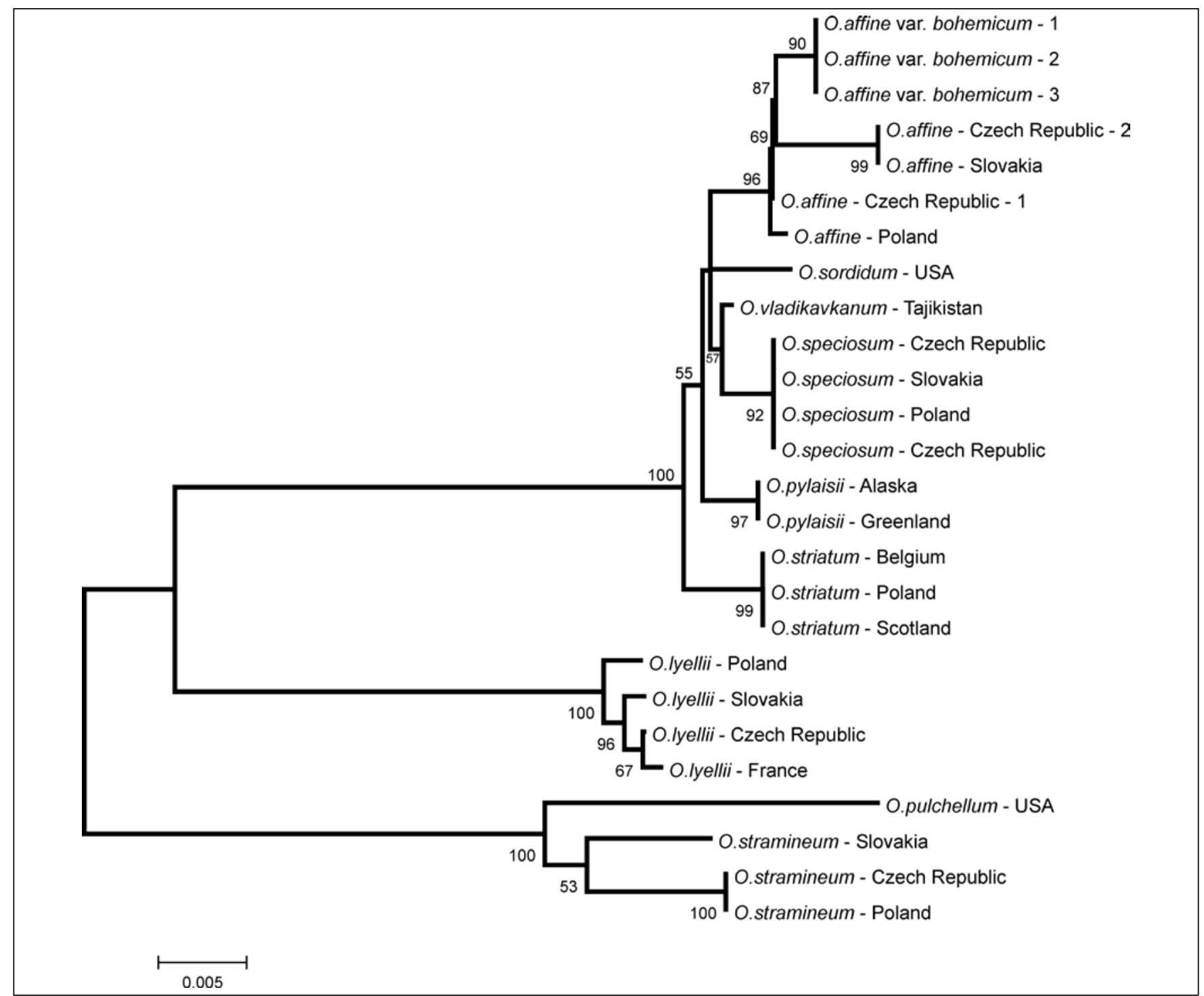

Fig. 5 Minimum evolution tree based on ITS sequences. Bootstrap values above 50\% are given above branches. 
is consistent with morphological data.

The samples of $O$. affine var. bohemicum differ from the specimens of $O$. affine from Slovakia and the Czech Republic (specimen 2) by one deletion and two substitutions, and from other specimens of $O$. affine (Poland and the Czech Republic 1) by additional three substitutions.

\section{Conclusion}

According to Lewinsky [2], the morphological features of Orthotrichum affine var. bohemicum, which were supported by the results of our molecular analysis [10], suggest its inclusion within the subgenus Gymnoporus, sect. Affinia.

The new taxon is closely related to type $O$. affine. These two taxa are morphologically similar with respect to the size of plants, leaf shape, and the type of stomates as well as the hairiness of calyptra. However, they differ significantly in the number of endostome segments $(O$. affine $=8, O$. affine var. bohemicum $=16$ ) and in the shape of leaf cell papillae. Whereas $O$. affine exceptionally rarely has forked branched papillae, $O$. affine var. bohemicum almost always develops forked papillae and rarely conical ones.

Subsequently, after we had distinguished the new species from the type-material, we also made a revision of selected Czech herbarium collections. As a result, two more specimens of $O$. affine var. bohemicum, reported from the territory of the Czech Republic, were found (Fig. 4). The first specimen was collected in the Bílé Karpaty Mts. in a locality near the village Velká nad Veličkou, $513 \mathrm{~m}$ a.s.l. (loc. No. 1 in the map, Fig. 4), on the bark of Tilia cordata, leg. V. Plášek 2006.04.21 (OP \#185624). The other one was found in the Hrubý Jeseník foothills, near the town of Rýmařov, in the Moravice river valley, $537 \mathrm{~m}$ a.s.l. (loc. No. 2 in the map, Fig. 4), on the bark of Salix fragilis, leg. V. Plášek 2006.10.15 (OP \#187354).

\section{Acknowledgments}

We thank Jarosław Proćków for help with developing the Latin diagnosis. Molecular work was supported by the Polish State Committee for Scientific Research (KBN grant N303 416237). SEM micrographs were made with help of Gabriela Kratošová. Article has been also done in connection with project Institute of environmental technologies, reg. No. CZ.1.05/2.1.00/03.0100 supported by Research and Development for Innovations Operational Programme financed by Structural Founds of Europe Union and from the means of state budget of the Czech Republic.

\section{Supplementary material}

The following supplementary material for this article is available online at https://pbsociety.org.pl/journals/index.php/ asbp/rt/suppFiles/asbp.2011.030/0:

1. Appendix S1. Accession data for plants included in the molecular analysis.

\section{References}

(Orthotrichaceae), a new epiphytic moss from Chile. Nova Hedw. 2007;131:1-11.

2. Lewinsky J. A synopsis of the genus Orthotrichum. Hedw. (Musci, Orthotrichaceae). Bryobrothera. 1993;2:1-59.

3. Kučera J, Váňa J. Seznam a červený seznam mechorostů České republiky (2004). Př́roda. 2005;23:1-104.

4. Plášek V, Sawicki J, Trávníčková V, Pasečná M. Orthotrichum moravicum (Orthotrichaceae), a new moss species from the Czech Republic. Bryologist. 2009;112(2):329-336. http://dx.doi.org/10.1639/0007-2745-112.2.329

5. Hill MO, Bell N, Bruggeman-Nannenga MA, Brugués M, Cano MJ, Enroth J, et al. An annotated checklist of the mosses of Europe and Macaronesia. J Bryol. 2006;28(3):198267. http://dx.doi.org/10.1179/174328206X119998

6. Grolle R, Long DG. An annotated check-list of the Hepaticae and Anthocerotae of Europe and Macaronesia. J Bryol. 2000;22:103-140.

7. Kubát K, Hrouda L, Chrtek J, Kaplan Z, Kirschner J, Štěpánek J, editors. Klič ke květeně České republiky. Praha: Academia; 2002.

8. Fiedorow P, Odrzykoski IJ, Szweykowska-Kulińska Z. Phylogenetic studies of liverworts using molecular biology techniques. In: Małuszyńska J, editor. Plant Cytogenetics. Katowice: Silesian University Press; 1998. p. 244-249.

9. Sawicki J, Plášek V, Szczecinska M. Preliminary studies on the phylogeny of Orthotrichum (Bryophyta) inferred from nuclear ITS sequences. Ann Bot Fennici. 2009;46:507-515.

10. Sawicki J, Plášek V, Szczecińska M. Molecular evidence does not support the current division of Orthotrichum subgenus Gymnoporus. Plant Syst Evol. 2009;279(1-4):125137. http://dx.doi.org/10.1007/s00606-009-0153-0

11. Sawicki J, Plášek V, Szczecińska M. Molecular studies resolve Nyholmiella (Orthotrichaceae) as a separate genus. J Syst Evol. 2010;48(3):183-194. http://dx.doi. org/10.1111/j.1759-6831.2010.00076.x

12. Plášek V, Sawicki J. Is the hairy vaginula a diagnostic feature in the taxonomy of the genus Orthotrichum. Acta Soc Bot Pol. 2010;79(1):73-80.

13. Edgar RC. Muscle: multiple sequence alignment with high accuracy and high throughput. Nucleic Acids Res. 2004;32(5):1792-1797. http://dx.doi.org/10.1093/nar/ gkh340

14. Hall TA. BioEdit: a user-friendly biological sequence alignment editor and analysis program for Windows 95/98/NT. Nucleic Acids Symp Ser. 1999;41:95-98.

15. Rzhetsky A, Nei M. A simple method for estimating and testing minimum-evolution trees. Mol Biol Evol. 1992;9(5):945-967.

16. Tamura K, Dudley J, Nei M, Kumar S. MEGA4: Molecular Evolutionary Genetics Analysis (MEGA) software version 4.0. Mol Biol Evol. 2007;24(8):1596-1599. http://dx.doi. org $/ 10.1093 / \mathrm{molbev} / \mathrm{msm} 092$

17. Kimura M. A simple method for estimating evolutionary rates of base substitutions through comparative studies of nucleotide sequences. J Mol Evol. 1980;16(2):111-120. http://dx.doi.org/10.1007/BF01731581

18. Nei M, Kumar S. Molecular evolution and phylogenetics. Oxford: Oxford University Press; 2000.

19. Felsenstein J. Confidence limits on phylogenies: an approach using the bootstrap. Evolution. 1985;39(4):783-791. http://dx.doi.org/10.2307/2408678 